\section{Amrinone before termination of cardio- pulmonary bypass: haemodynamic variables and oxygen utilization in the postbypass period}

James G. Ramsay MD FRCPC, Jose M. DeJesus MD,

J. Earl Wynands MD FRCPC, Fiona E. Ralley MB FFARCS,

J. Patrick O'Connor MD FRCPC,

G. Ross Robbins MD FRCPC, Jean Bilodeau BSc
One hundred patients were randomly allocated to receive saline or amrinone, $0.75 \mathrm{mg} \cdot \mathrm{kg}^{-1}$, ten minutes before separation from cardiopulmonary bypass (CPB) after elective coronary artery bypass grafting, in order to determine the effects of this agent on haemodynamic variables and $\mathrm{O}_{2}$ utilization. Anaesthesia and $C P B$ were managed in a standard fashion. Before induction of anaesthesia, at pericardiotomy, then at 1, 10,20 and $30 \mathrm{~min}$ after $C P B$, haemodynamic profiles, haematocrit, and $\mathrm{O}_{2}$ saturation of arterial and mixed venous blood were measured. Incremental doses of ephedrine or phenylephrine, or an infusion of norepinephrine with phentolamine were administered when required. The groups were demographically similar and surgical variables were also similar. Haemodynamic measurements were similar between groups at all times; however, a higher dose of phenylephrine was given immediately before weaning from $C P B$ in the amrinone group, and more patients in this group received

\section{Key words}

ANAESTHESIA: cardiac;

HEART: inotropism;

OXYGEN: consumption;

PHARMACOLOGY: amrinone;

SURGERY: cardiopulmonary bypass.

From the Departments of Anesthesia, Royal Victoria Hospital and McGill University, 687 Pine Avenue West, Montreal, Quebec, Canada H3A 1A1.

Address correspondence to: Dr. J.G. Ramsay, Emory University School of Medicine, Department of Anesthesiology, 1364 Clifton Road, N.E., Atlanta, GA 30322.

This work was funded in part by a grant from Winthrop Pharmaceuticals, and presented in part at the Canadian Anaesthetists' Society Meeting, June, 1988, Halifax, Nova Scotia.

Accepted for publication 16th December 1991. phenylephrine in the first $30 \mathrm{~min}$ after CPB. Mixed venous saturation $\left(\mathrm{SiO}_{2}\right)$ was higher in the amrinone patients at all times after $C P B$, leading to lower calculated oxygen consumption $\left(\dot{V} \mathrm{O}_{2}\right)(P<0.05)$. Insufficient dosage may explain the lack of haemodynamic effect, while possible reasons for the higher $\mathrm{SiO}_{2}$ and lower $\dot{\mathrm{V}} \mathrm{O}_{2}$ are either reduced whole body $\dot{\mathrm{V}} \mathrm{O}_{2}$ or peripheral shunting.

Afin de déterminer les effets de l'amrinone sur les paramètres hémodynamiques et sur l'utilisation de l'oxygène, 100 patients ont été désignés au hasard à recevoir soit du soluté physiologique, soit de l'amrinone $0,75 \mathrm{mg} \cdot \mathrm{kg}^{-1}$ dix minutes avant l'arrêt de la circulation extracorporelle (CEC) pour une chirurgie de revascularisation coronarienne non-urgente. L'anesthésie et la CEC ont été réalisées de la manière habituelle. Les paramètres hémodynamiques, l'hématocrite, et la saturation en $\mathrm{O}_{2}$ du sang artériel et veineux mêlé ont été mesurés avant l'induction de l'anesthésie, lors de la péricardectomie et à $1,10,20$ et 30 minutes après la CEC. Des doses progressives d'éphédrine ou de phényléphrine, ou une perfusion de norépinéphrine-phentolamine étaient administrées au besoin. Les groupes étaient identiques sur la plan de la démographie ainsi que des variables chirurgicales. Les mesures hémodynamiques ont été comparables en tout temps entre les deux groupes. Cependant, dans le groupe amrinone, une dose plus élevée de phényléphrine a dâ être administrée immédiatement avant le sevrage de la CEC et un plus grand nombre de patient ont dû recevoir ce médicament pendant les 30 minutes qui ont suivi la CEC. Après celle-ci, la saturation oxyhémoglobinée du sang veineux mêlé $\left(\mathrm{SìO}_{2}\right)$ a toujours été plus élevée chez les patients du groupe amrinone, ce qui a fait baisser la valeur calculée de la consommation d'oxygène $\left(\dot{V} \mathrm{O}_{2}\right)(P<0,05)$. Une dose insuffisante d'amrinone peut expliquer l'absence d'action hémodynamique, alors que la diminution de $\dot{V}_{2}$ systémique ou un effet shunt périphérique pourrait expliquer l'augmentation de la $\mathrm{Si}_{2}$ et la diminution de la $\dot{\mathrm{V}} \mathrm{O}_{2}$ 
Amrinone is a non-glycoside, non-catecholamine drug with both positive inotropic and vasodilator effects. ${ }^{1}$ It exerts its action by selectively inhibiting phosphodiesterase FIII, ${ }^{2}$ the enzyme responsible for the degradation of cyclic adenosine monophosphate (CAMP) which in turn has multiple actions within myocardial and vascular smooth muscle cells. ${ }^{2}$

Recently amrinone has been used in the treatment of chronic congestive heart failure ${ }^{3}$ and acute heart failure after cardiac surgery. ${ }^{4}$ Its effects included increased cardiac output (CO), decreased systemic vascular resistance (SVR), and decreased left and right heart filling pressures. In one study haemodynamic improvement was associated with a reduced myocardial oxygen consumption $\left(\mathrm{MVO}_{2}\right){ }^{5}$ Two recent reports describe the successful treatment of low $\mathrm{CO}$ states following cardiopulmonary bypass $(\mathrm{CPB})$ with amrinone after conventional measures had failed. ${ }^{6,7}$

Amrinone has not been used as first line therapy to aid weaning from $\mathrm{CPB}$. The purpose of this study was to determine if a bolus dose of the drug given just before the termination of CPB would be associated with improved haemodynamics and oxygen delivery, and a reduced requirement for other interventions after CPB in patients undergoing coronary artery bypass grafting (CABG).

\section{Methods}

With Ethics Committee approval and informed consent a randomized double-blind study was conducted. One hundred patients scheduled for elective $C A B G$ surgery were studied. All patients received premedication with diazepam $0.15 \mathrm{mg} \cdot \mathrm{kg}^{-1}$, morphine $0.1 \mathrm{mg} \cdot \mathrm{kg}^{-1}$ and scopolamine $0.4 \mathrm{mg}$ and their usual cardiac medication. On arrival in the operating room ECG leads $V_{5}$ and II and a pulse oximeter (Ohmeda Biox 3700, Ohmeda, Rexdale, Ontario, Canada) were applied. Intravenous, radial arterial, and pulmonary artery catheters were inserted under local anaesthesia. In 30 patients a fibreoptic pulmonary artery catheter (Opticath, Oximetrix Inc., Mountain View, California) was inserted, and in the remaining 70 patients a regular triple lumen thermistor-tipped pulmonary artery catheter (Spectramed) was used. Temperature probes were inserted in the nasopharynx and urinary bladder (Mon-aTherm "Cath Temp" Foley catheter) and continuously displayed on a Mon-a-Therm temperature monitor (Model 6000 , Mon-a-Therm Inc, St. Louis, MO) which was selfcalibrated at $25^{\circ} \mathrm{C}$ and $40^{\circ}$ before each study.

All patients were anaesthetized with sufentanil (3-10 $\mu \mathrm{g} \cdot \mathrm{kg}^{-1}$ ) and pancuronium $0.1 \mathrm{mg} \cdot \mathrm{kg}^{-1}$, supplemented with enflurane in oxygen. Cardiopulmonary bypass (CPB) was performed with a Stockert Shiley Modular Pump with a Shiley S100A bubble oxygenator and patients were cooled to $28^{\circ} \mathrm{C}$ nasopharyngeal temperature (NPT). The oxygenator had been primed with Ringer's lactate 1500 $\mathrm{ml}$, albumin $50 \mathrm{~g}$, and sodium bicarbonate $89 \mathrm{meq}$. Flow rates of $2.4 \mathrm{~L} \cdot \mathrm{m}^{-2}$ at normothermia, reduced to $1.5 \mathrm{~L} \cdot \mathrm{m}^{-2}$ at $28^{\circ} \mathrm{C}$, with a haematocrit maintained above $20 \%$, were used in all patients. Crystalloid cardioplegia (buffered Plegisol (Abbott), containing per liter $\mathrm{Ca}^{++} 2.4 \mathrm{mEq}, \mathrm{Mg}^{++}$ $32 \mathrm{mEq}, \mathrm{K}^{+} 16 \mathrm{mEq}, \mathrm{Na}^{+} 120 \mathrm{mEq}, \mathrm{Cl}^{-} 160 \mathrm{mEq}, \mathrm{HCO}_{3}^{-}$ $10 \mathrm{mEq} ; 324 \mathrm{mOsm}$ pH 7.8) was employed. Records were kept of the total bypass time, aortic crossclamp time, volume of cardioplegia used, estimated blood loss (weighed sponges plus wall suction, minus irrigation) and haematocrits and platelet counts before, during and after CPB. Mean arterial pressure (MAP) was maintained between $50-90 \mathrm{mmHg}$ using phenylephrine, or anaesthetic vapour (enflurane or isoflurane). No vapour was used in the 20 min before weaning from CPB.

After rewarming to an NPT of $37^{\circ} \mathrm{C}$ and urinary bladder temperature (UBT) of $34^{\circ} \mathrm{C}$, patients were randomly allocated to receive either amrinone 0.75 $\mathrm{mg} \cdot \mathrm{kg}^{-1}$ (Group A) or an equal volume of normal saline (Group S) infused over two minutes, ten minutes before weaning from CPB. The drug/saline was supplied in a foilwrapped syringe by the operating room pharmacist to blind the investigator. The oxygenator reservoir level and MAP were recorded before administration of the drug, and every two minutes thereafter for a total of ten minutes at which time the patient was weaned from CPB. Mean arterial pressure was divided by flow as an index of vascular resistance. Immediately before weaning from CPB if the MAP was $<60 \mathrm{mmHg}$, increments of phenylephrine, $25-100 \mu \mathrm{g}$, were given to achieve a MAP of $>60$ $\mathrm{mmHg}$. If ineffective, a norepi-nephrine infusion was started. If, as the heart was filled, pulmonary artery pressures increased with little change in systemic blood pressure, ephedrine in increments of $5 \mathrm{mg}$ was given. If ineffective, a norepinephrine infusion was started.

Following CPB, if pharmacologic support was required interventions were made by the attending anaesthetist not involved in the data collection. Interventions were limited to phenylephrine (25-100 $\mathrm{gg}$ increments) to increase blood pressure above $90 \mathrm{mmHg}$ systolic if associated with a cardiac index $(\mathrm{CI})>2.5 \mathrm{~L} \cdot \mathrm{min}^{-1} \cdot \mathrm{m}^{-2}$ and pulmonary capillary wedge pressure (PCWP) $12-18 \mathrm{mmHg}$. Ephedrine (5-10 mg increments) was used for myocardial stimulation if blood pressure was below $90 \mathrm{mmHg}$ associated with a CI $<2.5 \mathrm{~L} \cdot \mathrm{min}^{-1} \cdot \mathrm{m}^{-2}$ and PCWP > $15-18 \mathrm{mmHg}$. Where a more potent drug was required norepinephrine $16 \mu \mathrm{g} \cdot \mathrm{ml}^{-1}$ with phentolamine 20 $\mu \mathrm{g} \cdot \mathrm{ml}^{-1}$ was infused. Nitroglycerin was infused to treat high pulmonary artery pressures and/or new ST segment depression/elevation evident on the oscilloscope screen. Refractory LV failure (PCWP > 15-18, CI < 2.5) despite 
TABLE I Patient data: mean \pm SEM

\begin{tabular}{lcc}
\hline & Amrinone & Saline \\
\hline Age $(\mathrm{Yr})$ & $63 \pm 1$ & $62 \pm 1$ \\
Height $(\mathrm{cm})$ & $170 \pm 1$ & $171 \pm 1$ \\
Weight $(\mathrm{kg})$ & $76 \pm 2$ & $74 \pm 2$ \\
BSA $\left(\mathrm{m}^{2}\right)$ & $1.86 \pm 0.02$ & $1.85 \pm 0.02$ \\
Preoperative medications & & \\
- Beta blocker & 24 & 23 \\
- Calcium blocker & 37 & 36 \\
LV ejection fraction & $0.53 \pm 0.02$ & $0.51 \pm 0.02$ \\
Aortic crossclamp time & & \\
$\quad$ (min) & $52.5 \pm 3.6$ & $57.5 \pm 3.6$ \\
Total CPB time (min) & $98.0 \pm 3.6$ & $102.5 \pm 4.4$ \\
Volume of & & \\
$\quad$ cardioplegia (ml) & $1652 \pm 83$ & $1785 \pm 97$ \\
Blood loss (ml) & $947 \pm 94$ & $1060 \pm 72$ \\
No. of vessels grafted & $3.2 \pm 0.1$ & $3.6 \pm 0.1$ \\
& & \\
\hline
\end{tabular}

increasing norepinephrine dose was treated with intraaortic balloon counterpulsation.

Heart rate (HR), systolic and diastolic arterial pressure (SBP, DBP) mean pulmonary artery pressure (MPAP), PCWP, central venous pressure (CVP) and cardiac output were recorded immediately before induction of anaesthesia, at pericardiotomy and at 10,20, and $30 \mathrm{~min}$ following CPB. Cardiac output was determined by averaging three consecutive measurements derived by the thermodilution technique. $\mathrm{CI}$ and systemic vascular resistance (SVR) were derived in the usual fashion.

Oxygen delivery and utilization were measured at the same times as the haemodynamic variables. Before CPB, in patients with fibreoptic PA catheters, mixed venous haemoglobin saturation $\left(\mathrm{Sv}_{\mathbf{v}} \mathrm{O}_{2}\right)$ was read from the catheter and arterial saturation $\left(\mathrm{SaO}_{2}\right)$ read from the pulse oximeter. This allowed computation of oxygen contents using the method of "dual oximetry."

In patients without fibreoptic catheters mixed venous blood samples were analyzed for $\mathrm{Sv}_{2}$. In all patients, post-bypass arterial blood samples were analyzed for $\mathrm{SaO}_{2}$, with $\mathrm{SuO}_{2}$ obtained from the fibreoptic catheter when present or mixed venous blood. Oxygen content of blood $\left.\left(\mathrm{CaO}_{2}, \mathrm{CrO}\right)_{2}\right)$ was calculated as: $\mathrm{SO}_{2}(\%) \times$ haemoglobin $\left(\mathrm{g} \cdot \mathrm{dl}^{-1}\right) \times 1.39+\mathrm{PO}_{2} \times 0.003(\mathrm{vol} \%)$; oxygen consumption as $\mathrm{CI} \times \mathrm{CaO}_{2}-\mathrm{CvO}_{2}\left(\mathrm{ml} \cdot \mathrm{min}^{-1} \cdot \mathrm{m}^{-2}\right)$, oxygen delivery as $\mathrm{CI} \times \mathrm{CaO}_{2}\left(\mathrm{ml} \cdot \mathrm{min}^{-1} \cdot \mathrm{min}^{-2}\right)$, A-V $\mathrm{O}_{2}$ content difference as $\mathrm{CaO}_{2}-\mathrm{CvO}_{2}(\mathrm{ml})$, and $\mathrm{O}_{2}$ extraction ratio as $\mathrm{O}_{2}$ consumption $\div \mathrm{O}_{2}$ delivery (\%).

Differences between the two groups were compared using multivariate analysis of variance for repeated measures, Hotelling's $T^{2}$ test for paired data or chi square analysis for proportions. The null hypothesis was rejected when $P<0.05$.

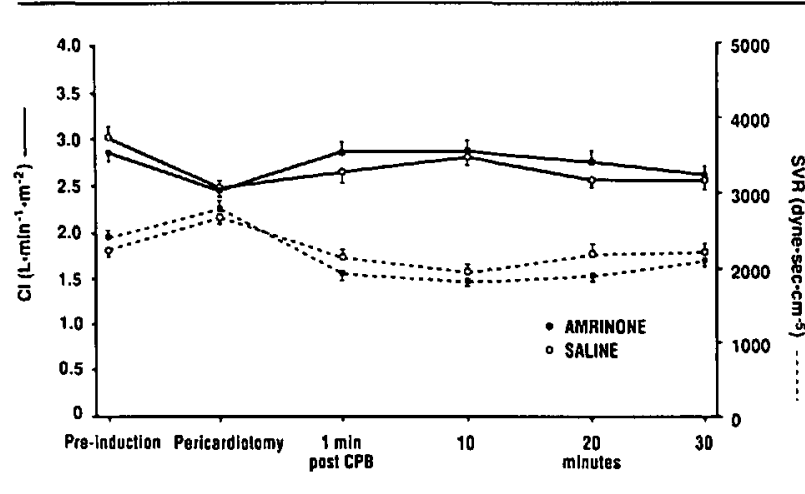

FIGURE 1 Cardiac index (Cl) and systemic vascular resistance (SVR). No differences were found between groups at any time.

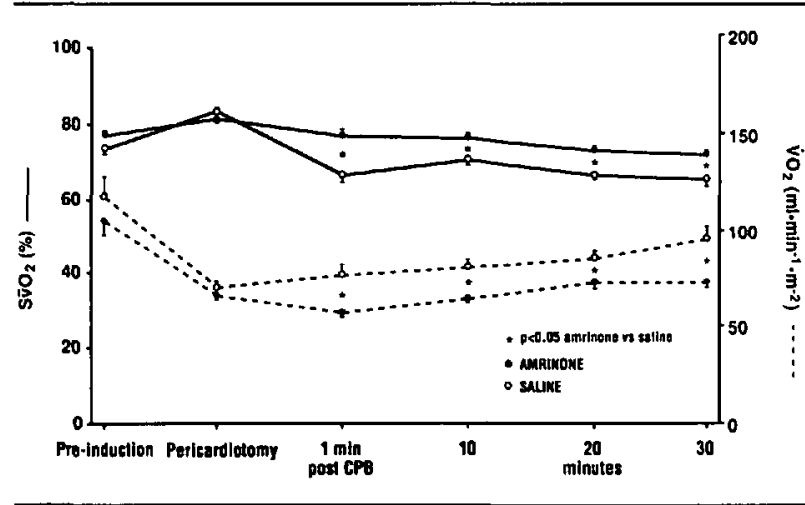

FIGURE 2 Mixed venous oxygen saturation $\left(\mathrm{S}^{2} \mathrm{O}_{2}\right)$ and oxygen consumption $\left(\mathrm{VO}_{2}\right)$. From $1 \mathrm{~min}$ to $30 \mathrm{~min}$ post-CPB $\mathrm{Sv}_{2}$ is higher and $\mathrm{VO}_{2}$ lower in the patients who received amrinone.

\section{Results}

There were 50 patients in each group. One patient in the amrinone group was excluded from the study when CPB was reinstituted $20 \mathrm{~min}$ after bypass because of a lacerated vein graft requiring repair. Ninety percent of patients in both groups had ejection fractions $>0.4$. The two groups were demographically similar (Table I).

In the ten minutes after the bolus dose of drug (before weaning from CPB) there were no haemodynamic differences between groups (Table II).

There were no differences between groups in any haemodynamic variable after CPB (Table III, Figure 1). There were no differences in haematocrit, $\mathrm{SaO}_{2}$ or $\mathrm{CaO}_{2}$ between groups (Table IV). The $\mathrm{SvO}_{2}$ was higher in the amrinone group at 1, 10,20 and $30 \mathrm{~min}$ after CPB $(P<$ $0.05)$.

While there was no difference in $\mathrm{O}_{2}$ delivery between groups at any time there were lower calculated $\mathrm{VO}_{2}, \mathrm{~A}-\mathrm{V}$ $\mathrm{O}_{2}$ content difference and $\mathrm{O}_{2}$ extraction ratio in the amrinone group from one to $30 \mathrm{~min}$ after $\mathrm{CPB}$ (Figure 2).

Immediately before weaning from $\mathrm{CPB}$ a higher dose of 
TABLE II Effect of amrinone bolus during cardiopulmonary bypass

\begin{tabular}{lllcc}
\hline & Drug & $n$ & Pre-bolus & 10 min post-bolus \\
\hline Pump flow & Amrinone & 49 & $4.5 \pm 0.1$ & $4.6 \pm 0.1$ \\
$\left(\mathrm{~L} \cdot \mathrm{min}^{-1}\right.$ ) & Saline & 50 & $4.5 \pm 0.1$ & $4.6 \pm 0.1$ \\
MAP* & Amrinone & 49 & $67 \pm 2$ & $65 \pm 2$ \\
(mmHg) & Saline & 50 & $68 \pm 2$ & $69 \pm 2$ \\
MAP/flow & Amrinone & 49 & $15.0 \pm 0.6$ & $14.6 \pm 0.7$ \\
(index of SVRt) & Saline & 50 & $15.4 \pm 0.5$ & $15.4 \pm 0.6$ \\
Reservoir level & Amrinone & 47 & & $290 \pm 48$ \\
decrease (ml) & Saline & 47 & & $209 \pm 32$ \\
\hline
\end{tabular}

"MAP = mean arterial pressure.

†SVR = systemic vascular resistance.

TABLE III Haemodynamic data (mean \pm SEM)

\begin{tabular}{|c|c|c|c|c|c|c|c|}
\hline & \multirow[b]{2}{*}{ Drug } & \multirow[b]{2}{*}{ Preinduction } & \multirow[b]{2}{*}{ Pericardiotomy } & \multicolumn{4}{|l|}{ Post-bypass } \\
\hline & & & & $(1 \mathrm{~min})$ & $(10 \mathrm{~min})$ & $(20 \mathrm{~min})$ & $(30 \mathrm{~min})$ \\
\hline HR & Amrinone & $63 \pm 2$ & $62 \pm 2$ & $77 \pm 2$ & $77 \pm 2$ & $77 \pm 2$ & $77 \pm 2$ \\
\hline (beats $\cdot \min ^{-1}$ ) & Saline & $65 \pm 2$ & $59 \pm 2$ & $74 \pm 2$ & $73 \pm 2$ & $75 \pm 2$ & $74 \pm 2$ \\
\hline SBP & Amrinone & $146 \pm 5$ & $127 \pm 3$ & $114 \pm 3$ & $114 \pm 2$ & $119 \pm 2$ & $119 \pm 2$ \\
\hline$(\mathrm{mmHg})$ & Saline & $141 \pm 3$ & $127 \pm 2$ & $108 \pm 2$ & $112 \pm 2$ & $117 \pm 2$ & $116 \pm 2$ \\
\hline DBP & Amrinone & $69 \pm 2$ & $68 \pm 2$ & $58 \pm 1$ & $58 \pm 2$ & $63 \pm 2$ & $65 \pm 1$ \\
\hline$(\mathrm{mmHg})$ & Saline & $67 \pm 2$ & $68 \pm 1$ & $61 \pm 2$ & $62 \pm 2$ & $66 \pm 2$ & $68 \pm 2$ \\
\hline MPAP & Amrinone & $21 \pm 1$ & $16 \pm 1$ & $21 \pm 1$ & $20 \pm 1$ & $19 \pm 1$ & $20 \pm 1$ \\
\hline$(\mathrm{mmHg})$ & Saline & $20 \pm 1$ & $18 \pm 0.5$ & $23 \pm 1$ & $21 \pm 1$ & $20 \pm 1$ & $20 \pm 1$ \\
\hline PCWP & Amrinone & $14 \pm 1$ & $11 \pm 0.5$ & $15 \pm 1$ & $15 \pm 1$ & $14 \pm 1$ & $14 \pm 1$ \\
\hline$(\mathrm{mmHg})$ & Saline & $13 \pm 1$ & $12 \pm 0.5$ & $17 \pm 1$ & $16 \pm 1$ & $14 \pm 1$ & $14 \pm 1$ \\
\hline CVP & Amrinone & $9 \pm 1$ & $8 \pm 1$ & $10 \pm 1$ & $10 \pm 1$ & $11 \pm 1$ & $12 \pm 1$ \\
\hline$(\mathrm{mmHg})$ & Saline & $8 \pm 1$ & $7 \pm 1$ & $10 \pm 1$ & $10 \pm 1$ & $11 \pm 1$ & $12 \pm 1$ \\
\hline CI & Amrinone & $2.8 \pm 0.1$ & $2.4 \pm 0.1$ & $2.8 \pm 0.1$ & $2.8 \pm 0.1$ & $2.7 \pm 0.1$ & $2.5 \pm 0.1$ \\
\hline$\left(L \cdot m^{-2}\right)$ & Saline & $3.0 \pm 0.1$ & $2.5 \pm 0.1$ & $2.6 \pm 0.1$ & $2.7 \pm 0.1$ & $2.5 \pm 0.1$ & $2.5 \pm 0.1$ \\
\hline SVR & Amrinone & $2439 \pm 97$ & $2811 \pm 111$ & $1947 \pm 96$ & $1842 \pm 79$ & $1924 \pm 91$ & $2131 \pm 97$ \\
\hline$\left(\right.$ dyne-sec $\cdot \mathrm{cm}^{-5}$ ) & Saline & $2280 \pm 100$ & $2705 \pm 86$ & $2167 \pm 109$ & $1969 \pm 99$ & $2218 \pm 119$ & $2218 \pm 112$ \\
\hline
\end{tabular}

See text for abbreviations.

phenylephrine was given in the amrinone group, and more patients in this group required phenylephrine in the first 30 min after CPB $(P<0.05)$ (Table V).

Although more patients in the saline group received ephedrine immediately before and in the first $30 \mathrm{~min}$ after weaning from CPB, this did not reach statistical significance. Comparison within groups of patients who either did or did not receive phenylephrine revealed no difference in $\mathrm{Sv}_{2}$.

Eleven patients in the amrinone group vs six in the saline group required pacing, and one patient in the amrinone group required an intraaortic balloon pump.

When analyzed separately, there were no differences between groups, in haemodynamic variables or drug requirements for those patients with $\mathrm{LV}$ ejection fraction $<0.4 \%$ (saline, 6 ; amrinone; 5).

Arterial $\mathrm{PCO}_{2}$ and $\mathrm{pH}$ were similar at all times between groups as were nasopharyngeal and urinary bladder temperatures. The platelet counts between groups were comparable at baseline, before drug administration and at one day after surgery (Table VI).

\section{Discussion}

This study demonstrates that amrinone $0.75 \mathrm{mg} \cdot \mathrm{kg}^{-1}$ given ten minutes before separation from CPB to patients undergoing elective $\mathrm{CABG}$ surgery resulted in higher $\mathrm{SVO}_{2}$ and lower calculated $\mathrm{VO}_{2}$ than patients who received placebo (saline).

The lack of demonstrated haemodynamic effects of amrinone may be due to several factors including dosage, patient population, degree of preexisting cardiac dysfunction, and our management technique. We gave the loading dose recommended by the manufacturer ten minutes before separation of CPB, as the peak effect from intravenous administration occurs at ten minutes. ${ }^{9}$ While larger bolus doses have been used (up to $3.5 \mathrm{mg} \cdot \mathrm{kg}^{-1}$ ) the 
TABLE IV Oxygen delivery and utilization (mean $\pm S E M$ )

\begin{tabular}{|c|c|c|c|c|c|c|c|}
\hline & \multirow[b]{2}{*}{ Drug } & \multirow[b]{2}{*}{ Preinduction } & \multirow[b]{2}{*}{ Pericardiotomy } & \multicolumn{4}{|l|}{ Post-bypass } \\
\hline & & & & $(I \min )$ & $(10 \mathrm{~min})$ & $(20 \mathrm{~min})$ & $(30 \mathrm{~min})$ \\
\hline Het & Amrinone & $40 \pm 1$ & $35 \pm 1$ & $23 \pm 1$ & $24 \pm 1$ & $24 \pm 1$ & $24 \pm 1$ \\
\hline$(\%)$ & Saline & $41 \pm 1$ & $36 \pm 1$ & $24 \pm 1$ & $24 \pm 1$ & $24 \pm 1$ & $25 \pm 1$ \\
\hline $\mathrm{CaO}_{2}$ & Amrinone & $18.4 \pm 0.4$ & $16.0 \pm 0.3$ & $10.2 \pm 0.5$ & $10.7 \pm 0.2$ & $10.6 \pm 0.2$ & $10.9 \pm 0.2$ \\
\hline (vol\%) & Saline & $17.5 \pm 0.4$ & $16.2 \pm 0.3$ & $10.6 \pm 0.4$ & $10.8 \pm 0.2$ & $10.9 \pm 0.2$ & $11.1 \pm 0.2$ \\
\hline $\mathrm{CvO}_{2}$ & Amrinone & $14.5 \pm 0.4$ & $13.1 \pm 0.3$ & $8.0 \pm 0.5$ & $8.3 \pm 0.2$ & $7.9 \pm 0.2$ & $7.9 \pm 0.2$ \\
\hline (vol\%) & Saline & $13.4 \pm 0.5$ & $13.3 \pm 0.3$ & $7.2 \pm 0.4$ & $7.8 \pm 0.2$ & $7.3 \pm 0.2$ & $7.4 \pm 0.2$ \\
\hline $\mathrm{SaO}_{2}$ & Amrinone & $98 \pm 1$ & $99 \pm 1$ & $99 \pm 1$ & $99 \pm 1$ & $99 \pm 1$ & $99 \pm 1$ \\
\hline$(\%)$ & Saline & $96 \pm 1$ & $99 \pm 1$ & $99 \pm 1$ & $99 \pm 1$ & $99 \pm 1$ & $99 \pm 1$ \\
\hline $\mathrm{SvO}_{2}$ & Amrinone & $77 \pm 1$ & $81 \pm 1$ & $77 \pm 2 *$ & $76 \pm 1^{*}$ & $73 \pm 1^{*}$ & $72 \pm 1^{*}$ \\
\hline$(\%)$ & Saline & $74 \pm 2$ & $82 \pm 1$ & $67 \pm 2$ & $71 \pm 2$ & $67 \pm 1$ & $66 \pm 2$ \\
\hline$\dot{\mathrm{VO}}_{2}$ & Amrinone & $105 \pm 8$ & $66 \pm 3$ & $57 \pm 3 *$ & $64 \pm 3^{*}$ & $73 \pm 4^{*}$ & $73 \pm 3^{*}$ \\
\hline$\left(\mathrm{ml} \cdot \min ^{-1} \cdot \mathrm{m}^{2}\right)$ & Saline & $118 \pm 10$ & $60 \pm 3$ & $76 \pm 5$ & $81 \pm 4$ & $86 \pm 4$ & $96 \pm 6$ \\
\hline $\mathrm{O}_{2}$ delivery & Amrinone & $507 \pm 34$ & $381 \pm 13$ & $281 \pm 28$ & $298 \pm 12$ & $289 \pm 14$ & $278 \pm 12$ \\
\hline$\left(\mathrm{ml} \cdot \min ^{-1} \cdot \mathrm{m}^{2}\right)$ & Saline & $514 \pm 30$ & $399 \pm 13$ & $244 \pm 17$ & $296 \pm 11$ & $272 \pm 10$ & $282 \pm 11$ \\
\hline $\mathrm{A}-\mathrm{VO}_{2}$ & Amrinone & $3.9 \pm 0.2$ & $2.8 \pm 0.1$ & $2.2 \pm 0.1^{*}$ & $2.4 \pm 0.1^{*}$ & $2.7 \pm 0.1^{*}$ & $3.0 \pm 0.1^{*}$ \\
\hline diff. (vol\%) & Saline & $4.2 \pm 0.3$ & $3.2 \pm 0.3$ & $3.4 \pm 0.3$ & $3.5 \pm 0.3$ & $3.8 \pm 0.2$ & $4.3 \pm 0.3$ \\
\hline $\mathrm{O}_{2} \operatorname{ext}^{\mathrm{n}}$ & Amrinone & $21 \pm 1$ & $18 \pm 1$ & $22 \pm 2^{*}$ & $23 \pm 1^{*}$ & $26 \pm 1^{*}$ & $27 \pm 1^{*}$ \\
\hline ratio (\%) & Saline & $23 \pm 2$ & $17 \pm 1$ & $33 \pm 2$ & $29 \pm 2$ & $33 \pm 1$ & $35 \pm 2$ \\
\hline
\end{tabular}

$P<0.05$ between groups.

See text for abbreviations.

dose of $0.75 \mathrm{mg}$ is calculated to provide an inotropic effect without causing hypotension secondary to the vasodilator properties of the drug. Since completion of this study, information has become available suggesting that after a dose of $0.75 \mathrm{mg} \cdot \mathrm{kg}^{-1}$ given during CPB, plasma concentrations of amrinone decrease below therapeutic levels in 20 min. ${ }^{10}$ This is a likely explanation for our findings.

The largest body of information about amrinone comes from patients with congestive heart failure. ${ }^{1-3}$ While an increase in cardiac output associated with a decrease in ventricular filling pressure has been repeatedly demonstrated, patients in these studies have typically had moderate to severe ventricular dysfunction with elevated filling pressures. Our patient population was different in that the majority had normal ventricular function, and the clinical context of an anaesthetized patient immediately after CPB is quite different from that of an awake patient in a coronary care unit. Perhaps only patients with severe ventricular dysfunction show haemodynamic improvement with amrinone in the recommended dose range, or anaesthetized patients after CPB respond differently from medical patients. The patients in this study with LVEF $<0.4$ showed no benefit from amrinone; however, the small number of patients precludes any conclusion from being drawn. Another explanation for the lack of haemodynamic effects may be drawn from the work of Wilmshurst $^{11}$ who contends that, in clinical doses, amrinone is only a vasodilator. The greater requirement for phenyleph- rine in the patients who received amrinone suggests that a vasodilating action was present.

One factor which may have contributed to the similar haemodynamic values in the two groups may have been the management with vasoactive/inotropic agents. Phenylephrine, ephedrine, and norepinephrine were given to obtain acceptable blood pressure ( $>90 \mathrm{mmHg}$ systolic) and cardiac index $\left(>2.5 \mathrm{~L} \cdot \mathrm{min}^{-1} \cdot \mathrm{m}^{-2}\right)$. If amrinone had elicited either an inotropic or a vasodilator effect the drug requirements might be expected to be different in that group. Only a modest effect with respect to phenylephrine requirements was observed (Table V).

The intriguing finding of this study was the higher $\mathrm{SvO}_{2}$, leading to a lower calculated $\mathrm{VO}_{2}$, and lower $\mathrm{A} \cdot \mathrm{VO}_{2}$ differences and oxygen extraction ratios in the patients who received amrinone. The measurement techniques and calculations were identical in both groups, and there were no differences in demographic features, temperatures or blood gases which could explain these findings. The $\mathrm{VO}_{2}$ at 30 min after CPB in the saline group was comparable to that found $90 \mathrm{~min}$ after $\mathrm{CPB}$ in nonshivering patients from this institution. ${ }^{12}$ Because $\mathrm{VO}_{2}$ was calculated as $\mathrm{A}-\mathrm{VO}_{2}$ content difference $\times \mathrm{CI}$, it is not possible to relate $\mathrm{CI}$ to $\mathrm{VO}_{2}$ independently. However, as CI was not different between groups, factors other than cardiac output must have contributed to the differences in $\mathrm{SvO}_{2}$.

Benotti et al. ${ }^{5}$ demonstrated a $30 \%$ reduction in $\mathrm{MVO}_{2}$ in patients with severe heart failure treated with amrinone. 
TABLE $\vee$ Drug requirement pre- and post-termination of cardiopulmonary bypass (mean \pm SEM (Range))

\begin{tabular}{|c|c|c|c|c|c|}
\hline . & \multirow[b]{2}{*}{ Study group } & \multicolumn{2}{|c|}{ Immediately before weaning } & \multicolumn{2}{|c|}{$0-30 \min$ post $-C P B$} \\
\hline & & $n$ & Dose & $n$ & Dose \\
\hline \multirow[t]{2}{*}{$\begin{array}{l}\text { Phenylephrine } \\
(\mu g)\end{array}$} & Amrinone & 21 & $\begin{array}{l}269 \pm 39 \\
(100-800)\end{array}$ & 12 & $\begin{array}{l}208 \pm 40 \\
(100-600)\end{array}$ \\
\hline & Saline & 17 & $\begin{array}{l}156 \pm 103^{*} \\
(50-500)\end{array}$ & $3 \dagger$ & $\begin{array}{l}167 \pm 67 \\
(100-300)\end{array}$ \\
\hline \multirow[t]{2}{*}{$\begin{array}{l}\text { Ephedrine } \\
(\mathrm{mg})\end{array}$} & Amrinone & 7 & $\begin{array}{l}9 \pm 1 \\
(5-15)\end{array}$ & 4 & $\begin{array}{l}11 \pm 1 \\
(10-15)\end{array}$ \\
\hline & Saline & 14 & $\begin{array}{l}8 \pm 1 \\
(5-15)\end{array}$ & 11 & $\begin{array}{l}11 \pm 2 \\
(5-25)\end{array}$ \\
\hline \multirow[t]{2}{*}{$\begin{array}{l}\text { Norepinephrine } \\
\left(\mu g \cdot \mathrm{kg}^{-1} \cdot \min ^{-1}\right)\end{array}$} & Amrinone & 2 & $\begin{array}{l}0.13 \pm 0.09 \\
(0.04-0.22)\end{array}$ & 6 & $\begin{array}{l}0.07 \pm 0.02 \\
(0.01-0.11)\end{array}$ \\
\hline & Saline & 2 & $\begin{array}{l}0.09 \pm 0.06 \\
(0.03-0.16)\end{array}$ & 11 & $\begin{array}{l}0.30 \pm 0.18 \\
(0.01-2.13)\end{array}$ \\
\hline \multirow{3}{*}{$\begin{array}{l}\text { Nitroprusside } \\
\left(\mu \mathrm{g} \cdot \mathrm{kg}^{-1} \cdot \mathrm{min}^{-1}\right) \\
\text { Nitroglycerin } \\
\left(\mu \mathrm{g} \cdot \mathrm{kg}^{-1} \cdot \mathrm{min}^{-1}\right)\end{array}$} & $\begin{array}{l}\text { Amrinone } \\
\text { Saline }\end{array}$ & $\begin{array}{l}0 \\
0\end{array}$ & $\begin{array}{l}- \\
-\end{array}$ & $\begin{array}{l}1 \\
1\end{array}$ & $\begin{array}{l}1.9 \\
0.2\end{array}$ \\
\hline & Amrinone & 2 & $\begin{array}{l}0.2 \pm 0.1 \\
(0.04-0.28)\end{array}$ & 7 & $\begin{array}{l}0.9 \pm 0.2 \\
(0.15-1.54)\end{array}$ \\
\hline & Saline & 4 & $\begin{array}{l}0.5 \pm 0.2 \\
(0.14-0.81)\end{array}$ & 11 & $\begin{array}{l}0.7 \pm 0.1 \\
(0.15-1.49)\end{array}$ \\
\hline
\end{tabular}

$* P<0.05$ (unpaired $t$ test) phenylephrine dose.

$\dagger P<0.05$ (chi-square) no. patients requiring phenylephrine.

TABLE VI Platelet count $\left(\times 10^{3}\right.$, mean $\left.\pm \mathrm{SEM}\right)$

\begin{tabular}{llll}
\hline & Ward & Pre-drug & $24 \mathrm{hr}$ \\
\hline Amrinone & $265 \pm 9$ & $152 \pm 6$ & $154 \pm 7$ \\
Saline & $234 \pm 1$ & $138 \pm 6$ & $134 \pm 7$ \\
\hline
\end{tabular}

A similar effect in our patients might have contributed to the higher $\mathrm{SvO}_{2}$ we observed. However, in the study by Benotti haemodynamic variables improved. While we did not measure $\mathrm{MVO}_{2}$ it has been shown to be in the order of $5-10 \mathrm{ml} \cdot \mathrm{min}^{-1}$ in a similarly anaesthetized group of patients immediately after $\mathrm{CPB} .{ }^{13}$ In the face of a whole body $\dot{\mathrm{VO}}_{2}$ in the order of $60-80 \mathrm{ml} \cdot \mathrm{min}^{-1} \cdot \mathrm{m}^{-2}$ (or $100-150 \mathrm{ml} \cdot \mathrm{min}^{-1}$ ) even a dramatic reduction in $\mathrm{MVO}_{2}$ could not have accounted for a lower whole body $\mathrm{VO}_{2}$ in the amrinone group.

Two possible explanations for the higher $\mathrm{SvO}_{2}$ in the patients who received amrinone are that the drug either reduced total body $\mathrm{VO}_{2}$, or that it caused peripheral shunting of arterial blood. While there are no data from humans, in anaesthetized dogs amrinone did not alter whole body $\mathrm{VO}_{2}{ }^{14}$ These findings may not be applicable to the patient after hypothermic CPB, but suggest that alteration in whole body $\mathrm{VO}_{2}$ may not be the explanation for our findings.

Peripheral shunting may occur with amrinone. In a dog model, instrumented to study diaphragmatic muscle blood flow and $\dot{\mathrm{VO}}_{2}$, Bundy $e t$ al. ${ }^{15}$ found that amrinone decreased the autoregulatory relationship between blood flow and pressure, and augmented both flow and the reactive hyperaemia after intense contraction. They postulated that the increased flow was "nonnutrient" or the equivalent of shunting. Application of these findings to those of the present study may not be appropriate, however, as in our patients there was no increased flow (i.e., CI was the same in both groups). If amrinone caused shunting without augmenting flow, metabolic acidosis should have developed in the amrinone group, but did not. Metabolic acidosis did not develop in patients treated with amrinone in the studies quoted in this paper, nor has it been suggested that other vasodilators (e.g., nitroprusside) elevate $\mathrm{SvO}_{2}$ by $\mathrm{A}-\mathrm{V}$ shunting. Therefore, despite the findings of Bundy et al., ${ }^{15}$ it seems unlikely that A-V shunting could explain the elevated $\mathrm{SvO}_{2}$ in the amrinone group.

Finally, it is possible that the greater use of phenylephrine in the amrinone group (rather than the amrinone itself) resulted in changes of peripheral flow distribution such that loss of oxygen extraction occurred. This would lead to a higher $\mathrm{Sv}_{2}$. We are not, however, aware of any studies reporting such effects of vasoconstricting drugs. In addition, the $\mathrm{SvO}_{2}$ was not different in those patients who received phenylephrine vs those who did not.

These results await confirmation from other perioperative studies where myocardial and whole body oxygen 
consumption are measured, independent of cardiac output, with and without amrinone. If a reduced $\mathrm{VO}_{2}$ is confirmed, our findings may explain, at least in part, the beneficial effects of this agent in patients with severe cardiac failure. That is, simultaneous with a modest inotropic and vasodilator action (which we were not able to detect in patients with good ventricular function after a dose of $0.75 \mathrm{mg}$. $\mathrm{kg}^{-1}$ ), there may be a reduction in whole body oxygen demand. This would result in a more favourable balance between oxygen delivery and demand, hence a higher $\mathrm{SivO}_{2}$.

In summary, we have been unable to document a beneficial haemodynamic effect of amrinone 0.75 $\mathrm{mg} \cdot \mathrm{kg}^{-1}$ in patients with good ventricular function during weaning from CPB after elective CABG surgery. This may be explained by inadequate dosage, and our aggressive treatment of haemodynamic abnormalities may also have obscured any drug effect. An unexpected finding was an increased $\mathrm{Sv}_{2}$ in patients who received amrinone. This led to a lower $\mathrm{VO}_{2}$ in these patients in the $30 \mathrm{~min}$ after CPB. While $\mathrm{MVO}_{2}$ was not measured, it seems unlikely that a reduction in $\mathrm{MVO}_{2}$ could have accounted for the higher $\mathrm{Sv}_{2}$ in the absence of haemodynamic changes. Therefore, we postulate that amrinone is either able to reduce whole body $\mathrm{VO}_{2}$ by an unidentified mechanism, or causes an increase in peripheral shunting.

\section{References}

1 Colucci WS, Wright RS, Braunwald E. New positive inotropic agents in the treatment of congestive heart failure (Part Two). N Engl J Med 1986; 314: 349-58.

2 Mancini $D$, LeJemtel $T$, Sonenblick $E$. Intravenous use of amrinone for the treatment of the failing heart. Am J Cardiol 1985; 56: 8B-15B.

3 Konstam MA, Cohen SR, Weiland, DS et al. Relative contribution of inotropic and vasodilator effects to amrinone induced hemodynamic improvement in congestive heart failure. Am J Cardiol 1986; 57: 242-8.

4 Goenen M, Pedemonte O, Baele P, Col J. Amrinone in the management of low cardiac output after open heart surgery. Am J Cardiol 1985; 56: 33B-38B.

5 Benotti JR, Grossman W, Braunwald E, Carabello $B A$. Effects of amrinone on myocardial energy metabolism and hemodynamics in patients with severe congestive heart failure due to coronary artery disease. Circulation 1980; 62: 28-34.

6 MacGillivray RG, Crause L, Odell JA, Rozwadowski $M A$. Amrinone after cardiopulmonary bypass surgery. $S$ Afr Med J 1985; 67: 426-7.

7 Robinson RJS, Tchervenkov C. Treatment of low cardiac output after aortocoronary artery bypass surgery using a combination of norepinephrine and amrinone. Journal of Cardiothoracic Anesthesia 1987; 1: 229-33.

8 Rasanen J, Downs JB, Hodges MR. Continuous monitoring of gas exchange and oxygen use, with dual oximetry. Journal of Clinical Anesthesia 1988; 1: 3-8.

9 LeJembel TH, Keung E, Schwartz W, et al. Hemodynamic effects of intravenous and oral amrinone in patients with severe heart failure: relationships between intravenous and oral administration. Trans Assoc Am Physicians 1979; 92: 325-33.

10 Bailey JM, Levy JH, Rogers HG, Szlam F, Hug CC. Pharmacokinetics of amrinone during cardiac surgery. Anesthesiology 1991; 75: 961-8.

11 Wilmshurst PT, Thomson DS, Juel SM. Effects of intracoronary and intravenous amrinone infusions in patients with heart failure and patients with near normal cardiac function. Br Heart J 1986; 53: 493-506.

12 Ralley $F E$, Wynands JE, Ramsay JG, Carli F, MacSullivan $R$. The effects of shivering on oxygen consumption and carbon dioxide production in patients rewarming from hypothermic cardiopulmonary bypass. Can J Anaesth 1988; 35: 332-7.

13 Moffitt EA, McIntyre AJ, Barker RA, et al. Myocardial metabolism and hemodynamic responses with fentanylenflurane anesthesia for coronary arterial surgery. Anesth Analg 1986; 65: 46-52.

14 Kosugi I, Gonda T, Okada K, Tajimik K, Mariyaso N, Fukatsu $O$. The effect of amrinone on hemodynamics, metabolism, and oxygen consumption in the anesthetized dog. Masui 1985; 34: 429-33.

15 Bundy RJ, Arnold JS, DiMarco AF, Hussein F, Supinski GS. Effect of amrinone on diaphragm blood flow. J Appl Physiol 1988; 65: 1506-13. 